\title{
Potassium mobilizing bacteria: enhance potassium intake in paddy to regulates membrane permeability and accumulate carbohydrates under salinity stress
}

\section{Yachana Jha}

N. V. Patel College of Pure and Applied Sciences. S. P. University. V.V. Nagar. Anand (Gujarat). India. Email: yachanajha@ymail.com.

\begin{abstract}
Potassium is one of the important key elements in terms of quantitative plant requirement. Although it is abundant in soils, in both organic and inorganic forms, but its availability is restricted as it occurs mostly in insoluble forms. Soil bacteria inhabiting around/on the root surface and facilitate the plant growth by various methods has been isolated from the paddy rhizosphere. Among many isolates, two isolates Bacillus pumilus and Pseudomanas pseudoalcaligenes were evaluated for their ability to solubilize potassium to help plant in its growth promotion in the greenhouse condition. Selected bacteria were analysed for their potassium solubilizing ability on different sources and also for various growth related physiology including accumulation of carbohydrate as osmoprotectant under saline stress. Potassium solubilizing bacteria (KMB) protect the plants from salinity injury by enhancing its growth related physiology like, stomatal conductance, electrolyte leakage and lipid peroxidation. Plant inoculated with potassium mobilizing bacteria (KMB) also accumulate more type and number of soluble carbohydrates analyzed by GCMS analysis in leaves under salinity, which helps the plant to overcome osmotic stress.
\end{abstract}

Keywords: KMB; Paddy; Photosynthesis; Cell membrane stability; Stomatal conductance; Electrolyte leakage; Salinity.

\section{Introduction}

Saline soil is distributed throughout the world, especially in the arid and semiarid regions where agriculture performs under irrigation. The potassium deficiency frequently compounds the problems of saline soil. High salinity affects plant growth through osmotic effects, altering plant physiology, and ultimately the production. It also suppresses the potassium uptake by plant roots and reduces the absorption processes of available potassium and also reduced the solubility of the $\mathrm{K}$ mineral. During evolution, plants have developed a wide range of mechanisms to resist a variety of stress conditions. Potassium is the seventh most abundant element in the Earth's crust, yet only one to two percent is available to plants and rest is fixed with other minerals and un-available to plants. Potassium helps plants to resist drought, the effects of excessive temperatures and also increases crop resistance to disease. Potassium aids plants in the production of starches, controls root growth, and regulates the opening and closing of stomata, which is important for efficient water use. The previous study suggests that mineral 
nutrients play a critical role in plant stress resistance by maintaining the mineral and water homeostate. Salt stress adversely affects plant nutrient acquisition, resulting in an important reduction in shoots dry biomass. Salt stress-induced osmotic stress, can additionally enhance the K-deficiency in plants (Romheld and Kirkby 2010). Under saline stress, photosynthetic $\mathrm{CO}_{2}$ fixation in K-deficient plants is substantially limited by the impairment in stomata regulation, conversion of light energy into chemical energy and phloem export of photosynthates from source leaves into sink organs (Egilla et al., 2005).

Consequently, increasing attention toward environment-friendly alternative to replace potassium fertilizers is gaining interest. The use of plant growth-promoting potassium solubilizing bacteria (KMB) and symbiotic microorganisms, may prove useful in developing strategies to facilitate plant growth in low potassium saline soils. Potassium Solubilizing Bacteria (KMB) can transform the insoluble potassium to soluble forms by acidification, chelation, exchange reactions and polymeric substances formation (Bhattacharyya and Jha, 2012).Therefore, the use of KMB in agricultural practice would not only offset the high cost of manufacturing potassium fertilizers but would also mobilize insoluble potassium in the fertilizers and soils to which they are applied. Inoculation of the KMB strongly promoted KMB populations, plant dry biomass, root/shoot dry weight ratio and nutrient uptake by plants, regardless of salinity level. The findings suggest that KSM inoculation alleviates the deleterious effects of salt on plant growth by enabling greater nutrient (e.g., $\mathrm{P}, \mathrm{N}$ and K) absorption, higher accumulation of ions in root tissues, when salinity is within acceptable limits. More specifically, the soil-borne Pseudomonas has received particular attention because of their catabolic versatility, excellent rootcolonizing ability and capacity to produce a wide range of enzymes and metabolites that help the plant withstand varied biotic and abiotic stress conditions. The B. subtilis strain could also alleviate the effects of salinity stress in soybean and treatment with the $B$. cereus alleviated the adverse effect of salinity in terms of decrease in growth, the number of leaves and shoot and root dry mass in the plant (Chakraborty et al., 2011). The interaction of KMB and their effect on the physiological response of paddy under salinity has not been studied in detail. We hypothesize that inoculation with a KMB, alone or in combination, can confer salinity tolerance to paddy and enhance $\mathrm{K}$ availability, such tolerance is correlated with changes level of oxidative damage of lipid peroxidation activity, photosynthesis rate, leaf greenness, and growth promotion parameters. The effect of isolated KMB has also been studied on the accumulation of different carbohydrate in leaves during GCMS analysis under salinity.

\section{Materials and methods}

Isolation, identification of KMB and analysis of its potassium solubilizing ability

Root associated bacteria were isolated (Jha et al., 2011) and identified by 16S rDNA analysis from the rice field as per our published method (Jha and Subramanian, 2013a). The growth promotion efficiency of the isolates was analyzed by their ability to solubilize potassium. Potassium solubilization by the isolates was studied on modified Aleksandrov medium plates by the spot test method. Plates of modified Aleksandrov medium having mica powder (an insoluble form of potassium) were prepared. A loopful of $48 \mathrm{~h}$ old grown rhizobacteria $\left(10 \mu \mathrm{L}\right.$ of $\left.10^{6} \mathrm{CFU} \mathrm{mL}^{-1}\right)$ was spotted on Aleksandrov medium plates. Plates were incubated at $28 \pm 2{ }^{\circ} \mathrm{C}$ for 3 days and potassium solubilization was based upon the ability of the solubilization zone formation.

\section{Quantitative estimation of potassium release}

A loopful of $48 \mathrm{~h}$ old grown bacterial culture was inoculated into $25 \mathrm{~mL}$ Aleksandrov medium broth in $50 \mathrm{~mL}$ capacity flask and incubated at $28+2{ }^{\circ} \mathrm{C}$ for 10 days. The growth suspension was centrifuged at $7,000 \mathrm{~g}$ for $10 \mathrm{~min}$ to 
separate the supernatant from the cell growth and insoluble potassium. $1 \mathrm{~mL}$ of the supernatant was taken in a $50 \mathrm{~mL}$ volumetric flask and the volume was made to $50 \mathrm{~mL}$ with distilled water and mixed thoroughly. The solution was fed to atomic absorption spectrometer to determine $\mathrm{K}$ content (Meena et al., 2014). A standard curve was prepared using various concentrations of $10 \mathrm{ppm} \mathrm{KCl}$ solution. The amount of potassium solubilized by the bacterial isolates was calculated from the standard curve.

\section{Estimation of titratable acidity and gluconic acid production}

Titratable acidity (TA) was determined by titrating $1 \mathrm{~mL}$ of culture filtrate against $10 \mathrm{mM} \mathrm{NaOH}$ in presence of phenolphthelein (Whitelaw et al., 1999). For estimation of organic acid released by cultures, $1 \mathrm{~mL}$ of culture supernatant was used. The volume was made to $5 \mathrm{~mL}$ with distilled water. To this $0.05 \mathrm{~mL}$ ammonia ammonium chloride, $0.05 \mathrm{~mL}$ magnesium sulphate $(0.5 \mathrm{M})$ and a pinch of Eriochrome $\mathrm{T}$ dye were added. This solution was titrated with $0.05 \mathrm{M}$ ethylene diamine tetraacetic acid (EDTA). The end point of the reaction was given by the appearance of blue color. The result was expressed in mmol L ${ }^{-1}$.

\section{Rice cultivation and inoculation}

Seeds of rice variety GR-11 were germinated and seedling was inoculated with isolates as per our published method (Jha and Subramanian, 2014a). Seven days old KMB inoculated rice plants were carefully removed from different test tubes inoculated with the strain of bacterium, and planted in a pot. Similarly, the control plants (un-inoculated) were also transferred to a fresh pot. Soil samples were collected from wet rice fields possessing the following physio-chemical properties., $\mathrm{pH}$ 7.79, electrical conductivity $1,063 \mu \mathrm{S} / \mathrm{cm}$, CEC:3 cmol, organic carbon: 5,500 mg/kg, available nitrogen $200 \mathrm{mg} / \mathrm{dcm}^{2}$, available Ca: 12.1 cmol, available P 205 : 9.5 $\mathrm{mg} / \mathrm{dcm}^{2}$, available K 20 : $265 \mathrm{mg} / \mathrm{kg}$, Fe: $3.1 \mathrm{mg} / \mathrm{kg}$, Zn: 285 mg/kg, Mn: 3.7 mg/kg,
$\mathrm{Cu}: 2.2 \mathrm{mg} / \mathrm{kg}$. All seedlings were grown for 4 weeks without any fertilizer treatment. The experiment was conducted in a greenhouse at 20 to $25{ }^{\circ} \mathrm{C}$ with a relative humidity of $70 \%$ to $80 \%$.

Maintenance of saline stress
condition and effect on growth
parameters, photosynthetic rate, and
stomatal conductance
The saline condition was
maintained with the electrical conductivity (ECe) of soil saturation extract $5.4 \mathrm{dSm}^{-1}$. ECe of soil extract was monitored and adjusted on alternate days. To avoid osmotic shocks, $\mathrm{NaCl}$ concentration was gradually increased for four consecutive days, until the desired concentration was attained. A plastic bag was kept under each pot to collect excess water due to drainage. This water was re-introduced to the respective pot.

The growth parameters i.e., plant height, dry weight, leaf greenness and photosynthetic rate were recorded for each treatment after 45 days of sowing the seeds. For dry weight (DW) determination, the leaves and roots were dried at $70{ }^{\circ} \mathrm{C}$ for $48 \mathrm{~h}$ and weighed. The photosynthetic rate was measured by an open-system portable photosynthesis meter and stomatal conductance of plants was measured using fresh leaves by Li-Cor 6400 .

Estimation of electrolyte leakage

This technique is based on the increase of cellular membrane permeability and concomitantly greater electrolyte diffusion out of cells when leaf tissue is injured by a stress situation. The uppermost fully expanded leaves of 10 plants per treatment were immediately cut into discs of $0.8 \mathrm{~cm}$ diameter. The discs were washed briefly three times with deionized water to remove solutes released during cutting of the discs. Five discs of each leaf were then placed in a vial filled with $10 \mathrm{~mL}$ deionized water and maintained at $20^{\circ} \mathrm{C}$ for $4 \mathrm{~h}$. Electrolyte leakage was determined by measuring the electrical conductivity of the vial solution, using a conductivity meter and data were expressed as $\mathrm{mS} \mathrm{cm}^{-1}$. 


\section{Effect of KSM on accumulation of various carbohydrate in the leaf extract by GC-MS}

The leaves were shade dried and $20 \mathrm{~g}$ of the powdered leaf was soaked in $95 \%$ ethanol for $12 \mathrm{~h}$. The extract was filtered through Whatman filter paper No. 41 along with $2 \mathrm{~g}$ sodium sulphate to remove the sediments and traces of water in the filtrate. Before filtering, the filter paper along with sodium sulphate was wetted with $95 \%$ ethanol. The filtrate was then concentrated by bubbling nitrogen gas into the solution. The extract contained both polar and nonpolar phytocomponents of the plant material used. $2 \mu \mathrm{L}$ of this solution was employed for GC-MS analysis (Merlin et al., 2009).

GC-MS analysis was carried out on a GC clarus 500 Perkin Elmer system comprising an AOC-20i auto sampler and gas chromatography interfaced to a mass spectrophotometer (GC-MS) instrument employing the following condition. Column Elite - 1 fused silica capillary column $(30 \times$ $0.25 \mathrm{~mm}$ ID $\times$ IEM df, composed of $100 \%$ trimethyl poly siloxane) operating in electron impact mode at $70 \mathrm{eV}$; helium (99.999\%) was used as carrier gas at a constant flow of $1 \mathrm{~mL} / \mathrm{min}$ and an injection volume of $0.5 \mathrm{EI}$ was employed (split ratio of $1: 1)$ injector temperature $\left(280^{\circ} \mathrm{C}\right)$. The oven temperature was programmed from $110^{\circ} \mathrm{C}$ (isothermal for $2 \mathrm{~min}$ ), with an increase of $10 \mathrm{C} / \mathrm{min}$ to $200^{\circ} \mathrm{C}$, then $5 \mathrm{C} / \mathrm{min}$ to $280^{\circ} \mathrm{C}$, ending with a $9 \mathrm{~min}$ isothermal at $280^{\circ} \mathrm{C}$. Mass spectrum was taken at $70 \mathrm{eV}$; a scan interval of $0.5 \mathrm{~s}$.

\section{activity \\ Estimation of Lipid peroxidation}

Leaves (2 g) were used for enzyme extraction. The level of lipid peroxidation in leaf was determined in terms of malondialdehyde (MDA) content according to the method of Madhava Rao and Sresty (2000). The content of MDA, which is an end product of lipid peroxidation, was determined using the thiobarbituric acid reaction. MDA concentration was calculated from the absorbance at $532 \mathrm{~nm}$ and measurements were corrected for nonspecific turbidity by subtracting the absorbance at $600 \mathrm{~nm}$. The concentration of MDA was calculated using an extinction coefficient of $155 \mathrm{mM} \mathrm{cm}^{-1}$.

\section{Statistical analysis}

Each pot was considered as replicate and all of the treatments were repeated five times. A two-way analysis of variance (ANOVA) was performed using STATISTICA program. The means and calculated standard errors are reported. The significance was tested at 5\% level.

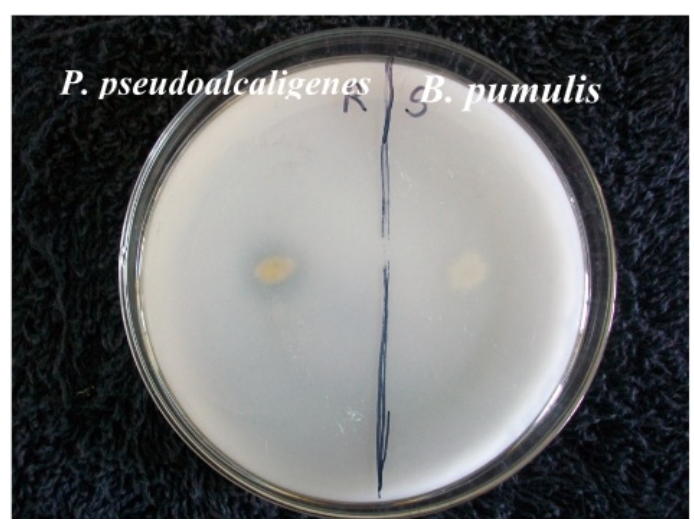

Figure 1. Modified Aleksandrov medium plates by showing the potassium solubilizing activity of $B$. pumulis and $P$. pseudoalcaligenes.

\section{Results}

Two bacterial isolates Pseudomonas pseudoalcaligenes and Bacillus pumilus (Figure 1) were selected from thirty five isolates obtained from the paddy field at the Botanical Garden of S. P. University, Gujarat, India and were found to be efficient with reference to their potassium solubilizing capability.

Both bacteria prefer neutral $\mathrm{pH}$ for their growth. Therefore, to determine the effect of $\mathrm{pH}$ on $\mathrm{K}$ solubilization, selected bacterial cultures were grown under different $\mathrm{pH}$ conditions. It was found that $\mathrm{K}$ solubilization was maximum when bacterial strains were grown in a medium with acidic $\mathrm{pH}$. As both the isolates were able to solubilize potassium with the production of organic acid as shown in Table 1 . The potassium released by $B$. pumilus was increased by 8.3 times and titratable acidity by 2.2 times after 1 week of inoculation, 
while by $P$.pseudoalcaligenes potassium solubilized was increased by 11.2 times and titratable acidity by 3.8 times after 1 week of inoculation in the medium. Bacterial isolates were also analyzed for potassium solubilization efficacy on different sources, and it was more efficient on simple compound than complex one. When amendment of different forms of potassium sources was made to replace mica powder in the medium, it was found that $\mathrm{K}$ solubilization by all the bacterial strains was much higher in $\mathrm{KCl}$ and $\mathrm{K}_{2} \mathrm{SO}_{4}$ amended medium broth than $\mathrm{AlK}\left(\mathrm{SO}_{4}\right)_{2} \cdot 12 \mathrm{H}_{2} \mathrm{O}$ and mica powder containing samples (Table 2). Potassium solubilization was lowest in the medium broth supplemented with mica powder.

The plants inoculated with KMB showed reduced growth suppression of paddy under salinity. The plant inoculated with KMB showed 22\% greater plant height and $43 \%$ greater plant height under salinity. Similarly, the dry weight increased by $18 \%$ and $36 \%$ in control and saline condition respectively (Table 3). Plants inoculated with P.pseudoalcaligenes and B. pumilus also showed higher leaf greenness and the photosynthetic rate compared to non-inoculated under both the conditions. The plant inoculated with KMB showed $4 \%$ higher leaf greenness in control and $11 \%$ higher leaf greenness under salinity. Similarly, the photosynthetic rate was also higher by $24 \%$ and $26 \%$ in the plant inoculated with KMB under stress. Stomatal conductance showed significant difference in KMB inoculated and noninoculated plants. It increased by $57 \%$ at non-saline state and $19 \%$ under saline stress in plant inoculated with both $P$. pseudoalcaligenes and B. pumilus in the control plants.

Table 1. Titratable acidity, organic acid concentration and $\mathrm{pH}$ during solubilization of potassium over incubation period of 1 week by the isolates $(n=5)$.

\begin{tabular}{|c|c|c|c|c|}
\hline \multirow[t]{2}{*}{ Days } & pH & $\begin{array}{c}\text { Potassium } \\
\text { solubilization }\end{array}$ & $\begin{array}{l}\text { Titratable acidity } \\
\left(\times\left(\times 10^{-2}\right)\right.\end{array}$ & $\begin{array}{c}\text { Organic Acid } \\
\left(\times 10^{-4} \mathrm{~g} \%\right)\end{array}$ \\
\hline & \multicolumn{4}{|c|}{ P. pseudoalcaligenes (Mean \pm S.D) } \\
\hline 3 & $7.0 \pm 0.01$ & $345.6 \pm 0.10$ & $10.02 \pm 0.2$ & $1.1 \pm 0.1$ \\
\hline \multirow[t]{2}{*}{7} & $4.8 \pm 0.05$ & $213.4 \pm 0.21$ & $28.5 \pm 0.10$ & $3.62 \pm 1.90$ \\
\hline & \multicolumn{4}{|c|}{ B. pumilus (Mean \pm S.D) } \\
\hline 3 & $7.0 \pm 0.05$ & $276.3 \pm 0.11$ & $9.01 \pm 0.1$ & $1.3 \pm 0.3$ \\
\hline 7 & $5.7 \pm 0.01$ & $189.2 \pm 0.32$ & $24.3 \pm 0.30$ & $10.20 \pm 2.29$ \\
\hline
\end{tabular}

Values are mean of three replications. ( $\mathrm{p} \leq 0.05$; LSD test).

Table 2. Solubilization of K from different sources by bacterial isolates.

\begin{tabular}{|c|c|c|c|c|}
\hline Sources of potassium & $\begin{array}{l}\text { Mica powder } \\
\left(\mathrm{mg} \mathrm{L}^{-1}\right)\end{array}$ & $\begin{array}{c}\mathrm{KCl} \\
\left(\mathrm{mg} \mathrm{L}^{-1}\right)\end{array}$ & $\begin{array}{l}\mathrm{K}_{2} \mathrm{SO}_{4} \\
\left(\mathrm{mg} \mathrm{l}^{-1}\right)\end{array}$ & $\begin{array}{c}\operatorname{AIK}\left(\mathrm{SO}_{4}\right)_{2} \cdot 12 \mathrm{H}_{2} \mathrm{O} \\
\left(\mathrm{mg} \mathrm{L}^{-1}\right)\end{array}$ \\
\hline $\begin{array}{l}\text { P. pseudoalcaligenes } \\
\text { B. pumilus }\end{array}$ & $\begin{array}{l}52.2 \pm 0.2 \\
36.3 \pm 0.6\end{array}$ & $\begin{array}{l}2,911.4 \pm 0.3 \\
2,712.6 \pm 0.1\end{array}$ & $\begin{array}{l}2,303 \pm 0.4 \\
2,354 \pm 0.8\end{array}$ & $\begin{array}{l}406.3 \pm 0.1 \\
411.2 \pm 0.2\end{array}$ \\
\hline
\end{tabular}

Values represent the amount of potassium solubilized by different bacteria in modified Aleksandrov medium broth amended with different sources of potassium. Values are expressed as means \pm standard deviation of three independent data 
Table 3. Effect of KMB on dry weight, plant height, leaf greenness, photosynthetic rate and potassium concentration under saline condition.

\begin{tabular}{|c|c|c|c|c|c|c|}
\hline $\begin{array}{l}\text { Salinity of } \\
\text { irrigation } \\
\text { water }\end{array}$ & Treatment & $\begin{array}{l}\text { Dry weight } \\
\left.\text { (g plant }^{-1}\right)\end{array}$ & $\begin{array}{c}\text { Plant } \\
\text { Height } \\
\text { (cm) }\end{array}$ & $\begin{array}{c}\text { Leaf } \\
\text { greenness } \\
\text { (SPAD) }\end{array}$ & $\begin{array}{l}\text { Photosynthetic } \\
\text { rate ( } \mu \text { molCO } \\
\left.\mathrm{m}^{-2} \mathrm{~s}^{-1}\right)(\mathrm{Li}-\mathrm{Cor})\end{array}$ & $\begin{array}{c}\text { Stomatal } \\
\text { Conductance } \\
\left(\mathrm{mol} \mathrm{m}^{-2} \mathrm{~s}^{-1}\right)\end{array}$ \\
\hline \multirow{4}{*}{$\begin{array}{l}0.3 \mathrm{dSm}^{-1} \\
\text { Control }\end{array}$} & No inoculation & $2.43^{d}$ & $82.1^{\mathrm{d}}$ & $52.3^{\mathrm{cd}}$ & $26.4^{d}$ & $0.69^{d}$ \\
\hline & With B. pumulis & $2.72^{\mathrm{bc}}$ & $89.3^{c}$ & $61.1^{\text {bc }}$ & $31.1^{\mathrm{c}}$ & $0.76^{\text {bc }}$ \\
\hline & With $P$. pseudoalcaligenes & $2.96^{\mathrm{ab}}$ & $94.2^{\mathrm{ab}}$ & $64.9^{\mathrm{ab}}$ & $33.7^{\mathrm{ab}}$ & $0.87^{b}$ \\
\hline & $\begin{array}{l}\text { With } B . \text { pumulis }+ \\
\text { P.pseudoalcaligenes }\end{array}$ & $2.98^{\mathrm{a}}$ & $98.4^{\mathrm{a}}$ & $67.2^{\mathrm{a}}$ & $34.3^{\mathrm{a}}$ & $0.98^{\mathrm{a}}$ \\
\hline \multirow[t]{4}{*}{$5.4 \mathrm{dSm}^{-1}$} & No inoculation & $1.81^{\mathrm{d}}$ & $44.1^{\mathrm{d}}$ & $38.2^{\mathrm{cd}}$ & $12.2^{\text {cd }}$ & $0.32^{\text {cd }}$ \\
\hline & With $B$. pumulis & $2.14^{\mathrm{bc}}$ & $57.5^{\mathrm{c}}$ & $43.3^{\text {bc }}$ & $16.2^{\mathrm{bc}}$ & $0.39^{\mathrm{c}}$ \\
\hline & With P. pseudoalcaligenes & $2.28^{\mathrm{ab}}$ & $53.7^{\mathrm{b}}$ & $44.1^{\mathrm{ab}}$ & $18.4^{\mathrm{ab}}$ & $0.45^{b}$ \\
\hline & $\begin{array}{l}\text { With } B . \text { pumulis }+ \\
\text { P.pseudoalcaligenes }\end{array}$ & $2.32^{\mathrm{a}}$ & $67.1^{\mathrm{a}}$ & $44.9^{\mathrm{a}}$ & $21.3^{\mathrm{a}}$ & $0.51^{\mathrm{a}}$ \\
\hline
\end{tabular}

Values are mean of three replications. Means within columns sharing the same letters are not significantly different $(\mathrm{P} \leq 0.05$; LSD test).

The solute leakage of the leaves did not showed any difference between inoculated and non-inoculated plants, but plants under salinity stress showed significantly higher electrolyte leakage in non-inoculated plant. Non-inoculated plants, under salinity stress, had significantly higher electrolyte leakage compared with inoculated plants (Figure 2).

\section{Electrolyte leakage}

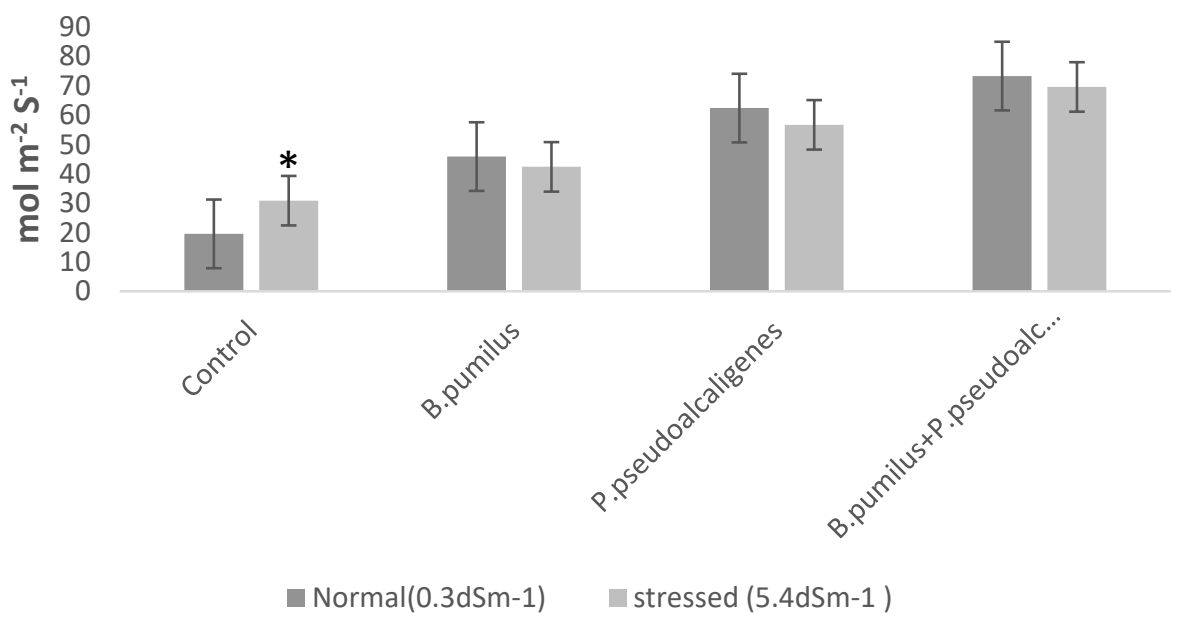

Figure 2. Effect of isolates on electrolyte leakage in paddy variety GR11 at normal and salinity stress $(\mathrm{n}=5)$.

GCMS analysis of leaf extract of inoculated and non-inoculated plants under salinity showed significant difference in the types of soluble carbohydrate accumulated under stress. The non-inoculated plant under salinity showed accumulation of 8 common carbohydrates, while plant inoculated with KMB showed 12 different carbohydrates under salinity (Table 4 and 5). 
Table 4. Different soluble carbohydrate in non-inoculated paddy leaves extract identified in GC-MS analysis under salinity.

\begin{tabular}{|c|c|c|c|c|c|c|}
\hline Hit & Rev & For & Compound name & M.W. & Formula & CAS \\
\hline 1 & 823 & 682 & D-galactose 6-deoxy & 184 & $\mathrm{C}_{8} \mathrm{H}_{12} \mathrm{O}_{5}$ & $3815-37-0$ \\
\hline 2 & 788 & 588 & Lactose & 342 & $\mathrm{C}_{12} \mathrm{H}_{22} \mathrm{O}_{11}$ & $63-42-3$ \\
\hline 3 & 774 & 625 & D-glucohexo dialdose & 178 & $\mathrm{C}_{8} \mathrm{H}_{10} \mathrm{O}_{8}$ & 900149-19-1 \\
\hline 4 & 772 & 608 & D-mannose & 180 & $\mathrm{C}_{6} \mathrm{H}_{12} \mathrm{O}_{6}$ & $3458-28-4$ \\
\hline 5 & 771 & 668 & L-mannose 6-deoxy & 184 & $\mathrm{C}_{6} \mathrm{H}_{12} \mathrm{O}_{6}$ & $3815-41-8$ \\
\hline 6 & 769 & 570 & D-glucose 4 -D- $\alpha$-D glucopyranosyl & 342 & $\mathrm{C}_{12} \mathrm{H}_{22} \mathrm{O}_{11}$ & $69-79-4$ \\
\hline 7 & 766 & 563 & $\begin{array}{l}\beta \text {-D glucopyranose } 4-\mathrm{D}-\beta \text { - } \\
\text { galactopyranosyl }\end{array}$ & 342 & $\mathrm{C}_{12} \mathrm{H}_{22} \mathrm{O}_{11}$ & $5965-66-2$ \\
\hline 8 & 765 & 558 & D-lyxose & 150 & $\mathrm{C}_{5} \mathrm{H}_{10} \mathrm{O}_{5}$ & $1114-34-7$ \\
\hline
\end{tabular}

Where hit means attempt Number, Rev $=$ Reverse match of peak, For $=$ Forward match of Peak, M.W. = Molecular weight of compound, CAS = Chemical Abstract Service.

Table 5. Different soluble Carbohydrate in KMB inoculated paddy leaves extract identified in GC-MS analysis under salinity.

\begin{tabular}{|c|c|c|c|c|c|c|}
\hline Hit & Rev & For & Compound name & M.W. & Formula & CAS \\
\hline 1 & 863 & 667 & Ethyl $\alpha$ - D-glucopyranoside & 208 & $\mathrm{C}_{8} \mathrm{H}_{16} \mathrm{O}_{6}$ & $900127-29-4$ \\
\hline 2 & 849 & 670 & $\alpha$ - D-galactopyranoside methyl 6-deoxy & 178 & $\mathrm{C}_{7} \mathrm{H}_{14} \mathrm{O}_{5}$ & $14887-15-1$ \\
\hline 3 & 834 & 508 & Ethyl $\beta$ D-riboside & 178 & $\mathrm{C}_{7} \mathrm{H}_{14} \mathrm{O}_{5}$ & 900128-95-4 \\
\hline 4 & 798 & 691 & L-Galactose 6-deoxy & 184 & $\mathrm{C}_{8} \mathrm{H}_{12} \mathrm{O}_{5}$ & $2438-80-4$ \\
\hline 5 & 796 & 637 & 2,3,4,5-tetrahydroxypbtanal & 150 & $\mathrm{C}_{8} \mathrm{H}_{10} \mathrm{O}_{5}$ & 53108-52-8 \\
\hline 6 & 796 & 585 & $\begin{array}{l}1,2,3,4-c y c l o p e n t a n e t e t r o l ~ 1-\alpha, 2-\beta, 3-\beta \text {, } \\
4-\alpha\end{array}$ & 134 & $\mathrm{C}_{8} \mathrm{H}_{10} \mathrm{O}_{4}$ & $14003-71-5$ \\
\hline 7 & 787 & 868 & B-D ribopyranoside methyl & 184 & $\mathrm{C}_{8} \mathrm{H}_{12} \mathrm{O}_{5}$ & 17289-61-1 \\
\hline 8 & 788 & 644 & L-lyxose & 150 & $\mathrm{C}_{8} \mathrm{H}_{10} \mathrm{O}_{5}$ & 1994-78-6 \\
\hline 9 & 781 & 580 & $\alpha$-rhamnopyranose & 164 & $\mathrm{C}_{8} \mathrm{H}_{12} \mathrm{O}_{5}$ & $35810-58-1$ \\
\hline 10 & 778 & 585 & $\begin{array}{l}\alpha \text {-D-glucopyranose } 4-0-\alpha-\mathrm{D} \text { - } \\
\text { galactopyranosl }\end{array}$ & 342 & $\mathrm{C}_{12} \mathrm{H}_{22} \mathrm{O}_{11}$ & 14641-83-1 \\
\hline 11 & 775 & 802 & $\begin{array}{l}\alpha \text {-D-glucopyranoside o- } \alpha \text {-D- } \\
\text { glucopyranosyl }\end{array}$ & 504 & $\mathrm{C}_{18} \mathrm{H}_{32} \mathrm{O}_{16}$ & $597-12-8$ \\
\hline 12 & 775 & 862 & 2,3,4,5-tetrahydroxy pentanal & 150 & $\mathrm{C}_{5} \mathrm{H}_{10} \mathrm{O}_{5}$ & $5310-52-8$ \\
\hline
\end{tabular}

Where hit means attempt Number, Rev Reverse match of peak, For Forward match of Peak, M.W. Molecular weight of compound, CAS Chemical Abstract service.

MDA content significantly increased in both inoculated as well as in non-inoculated plants under normal condition. But with the increase in soil salinity proportionally increased the MDA content in the non-inoculated plant has been observed. However, inoculation with KMB reduced the MDA content in the plant under salinity. It enhanced by 3 times in noninoculated plant, while inoculated plant showed decreased MDA activity by 2 times compared to control (Figure 3). 


\section{Lipid Peroxidation}

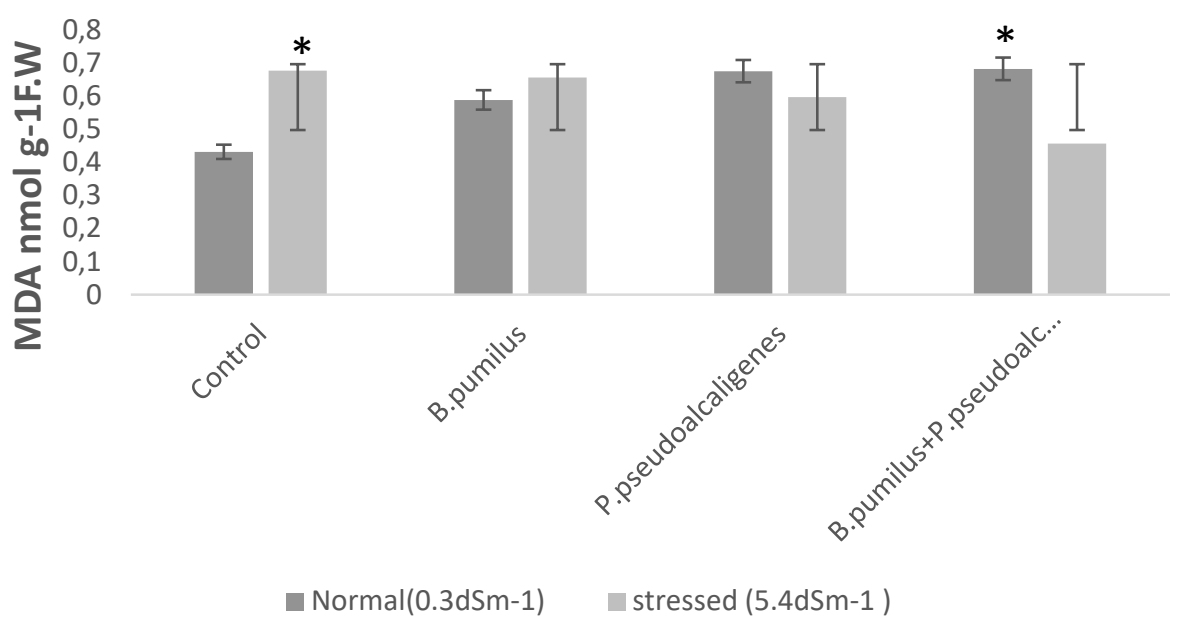

Figure 3. Effect of isolates on MDA content in paddy variety GR11 at normal and salinity stress $(n=5)$.

\section{Discussion}

Salinity plays a major role in limiting cellular processes; thus, dealing with such stress is very important for plant growth. Despite the high total soil potassium content in the soil, plant potassium availability is often reported to be limited, particularly in saline soils (Collavino et al., 2010). Most of the soil potassium is usually present as insoluble metal chelates; moreover, considerable amounts of applied chemical potassium fertilizers are also rapidly converted into insoluble potassium sources. This leads to regular applying of potassium fertilizers, which are not only costly, but also environmentally undesirable. This limitation require a search for an ecologically safe and economically reasonable option for improving crop production in low potassium soils. In this context, organisms coupled with potassium solubilizing activity, may mobilize the available potassium for the growth and development of plants and hence act as a viable substitute for chemical potassium fertilizers (Meena et al., 2015). The importance of rhizospheric microbial populations for maintaining the root health by various mechanism like enhanced nutrient uptake or to develop tolerance to environmental stress. The various KMB inhabiting the rhizosphere, are considered as promising biofertilizers since they can supply plants with potassium from different sources otherwise poorly available by various mechanisms. Bacterial genera like Azotobacter, Bacillus, Beijerinckia, Burkholderia, Enterobacter, Erwinia, Flavobacterium, Microbacterium, Pseudomonas, Rhizobium and Serratia are reported as the most significant mineral solubilizing bacteria (Bhattacharyya and Jha, 2012).

In the present study two bacterial isolates, P.pseudoalcaligenes and $B$. pumilus were found to be efficient with reference to their potassium mineralization capability. Bacterial genera such as Bacillus, Pseudomonas and Brevibacillus are known to be promoting growth and yield in different non-leguminous plants are also reported by Selvakumar et al. (2008). Zaidi et al. (2009) reported that the mineral solubilization by the bacteria could probably be due to secretion of organic acids, such as gluconic, 2-ketogluconic. Production of organic acids for solubilization of potassium is a well-known mechanism; the reason for the reduction in $\mathrm{pH}$ in the present study may also be due to production of organic acids by the isolates. The acidic $\mathrm{pH}$ has a role in the potassium 
solubilization has been supported by Meena et al. (2014) who reported that solubilization of potassium of $\mathrm{Ca}, \mathrm{Al}$ and Fe (III) increase in acidic condition. The negative correlation between $\mathrm{pH}$ and soluble potassium content of the medium, as well as the positive correlation between soluble potassium content and titratable acid production, suggest that acidification of the medium can facilitate better potassium solubilization. Co-inoculation showed a higher potassium solubilizing ability, suggesting the synergistic action of both the isolates in potassium solubilization (Yu et al., 2011).

The efficiency of potassium solubilization by different bacteria vary with the structure and chemical composition of the potassium bearing minerals. In the present study, the extent of potassium solubilization by P. pseudoalcaligenes in the liquid media was more and better compared to B. pumilus. This results suggest that effective potassium-solubilizing and plantgrowth promoting bacterial for plant systems must be tested further in controlled experimental designs with specific consideration of soil type, plant types grown and the environmental factors (Liu et al., 2006) for effective selection of isolates. Thus, potassium solubilizing bacteria isolated in present study could be tested for use in the amelioration of potassiumdeficient soils and may lead to an alternative source for improvement of potassium nutrition in sustainable agriculture under normal and saline stress.

The mechanisms used by plants to overcome the detrimental effects of saline stresses are very complicated, in which the growth and development mechanisms of the plants and the stress effectors mechanism need to be balanced. In this study, salinity adversely affect the growth of the selected paddy plant, regardless of the biological treatment and saline stress. Such reduction of plant growth is due to the alteration in many physiological activities of the plant, as photosynthetic activity, water conductance, mineral uptake and antioxidant activity. However, the plant inoculated with KMB showed greater plant growth under saline as well as non-saline state, the similar observation is reported by Kohler et al. (2009) also. Photosynthesis is the main ROS-producing process in chloroplasts, and ROS can cause photoinhibitory and photooxidative damage. Chlorosis is a common response to salinity, and it inhibit the photosynthesis process of the plant under stress. In the present study, leaf greenness and the photosynthetic rate were significantly higher in plants inoculated with $P$. pseudoalcaligenes and B. pumilus at non saline condition, as well as at different level of salinity compared to non-inoculated control plants. This may be because these isolates help the plants in water absorption and retention, finding are as per our previous study (Jha and Subramanian, 2013b). Salinity rapidly decreases stomatal conductance, resulted in a reduced transpiration rate. Stomata closure is known to be an effective mechanism for economical water utilization under salt stress and for the limitation of the harmful salt ion uptake. However inoculation with $\mathrm{KMB}$ result in increased stomatal conductance under saline and non-saline state to improve leaf water potential in adverse condition, observation is supported by Mia et al. (2010).

Adverse environmental factors cause cell membranes to lose selective permeability, cellular integrity and capacity for retention of intracellular substances. The cellular membrane dysfunction due to water stress causes an increase in the permeability and ion leakage. In this study, the electrolyte leakage is detected almost instantaneously after the application of salinity stress in inoculated as well as in non-inoculated plants, but inoculated plant showed less electrolyte leakage. It is mainly caused by the efflux of $\mathrm{K}^{+}$and so-called counter ions $\left(\mathrm{Cl}^{-}, \mathrm{HPO}_{4}{ }^{2-}, \mathrm{NO}_{3}{ }^{-}\right)$that move to balance the efflux of positively charged potassium ions. This is particularly important for the roots, where $\mathrm{K}^{+}$leakage is a common phenomenon leading to irreversible $\mathrm{K}^{+}$loss by plants during the stress response (Jha and Subramanian, 2014b). 
Different stress situations which directly or indirectly cause accumulation of ROS, are associated with soluble sugar accumulation, which has generally been considered to be an adaptive response to the stress condition. Carbohydrates such as soluble sugars (glucose, fructose, sucrose, fructans) accumulate under salt stress to accommodate the ionic balance in the Plant (Couée et al., 2006). Their major functions are osmoprotection, osmotic adjustment, carbon storage, radical scavenging and stabilization of the structure of proteins. In present study, the contribution of total soluble sugar accumulation in osmotic adjustment was significantly remarkable, since the total soluble sugar content increased with an increase in salinity both in inoculated and non-inoculated plants. However inoculated plant under salinity showed more types of soluble sugar in GCMS analysis. Similar results are obtained by Rejsiková et al., (2007), who reported that the concentrations of sugars change in response to salt stress in plants. Soluble sugar accumulation may be due to the further transformation of starch to sugars or less consumption of carbohydrates by the tissues in saline conditions. Although the relationship between saline stress and sugar accumulation is of great interest, it may be difficult to interpret because these situations of stress and the corresponding responses are clearly pleiotropic in terms of targets and therefore of protection mechanisms.

Soil salinity is well recognized for membrane lipid peroxidation and cause an increase in leaf malondialdehyde (MDA), a product of membrane lipid peroxidation. Therefore, leaf MDA content, representing the degree of cell membrane damage, is usually used to evaluate plant tolerance to salinity. Peroxidation of lipid membranes of plants reflects free radical-induced oxidative damage at the cellular level under salt stress. In the present study with an increase in soil salinity, there was a simultaneous increase in MDA. The results indicate strong agreement with the results of Sivritepe et al., (2008), who found decreased levels of lipid peroxidation in wheat cells when exposed to salt stress. The present study shows that P. pseudoalcaligenes in combination with $B$. pumilus having potassium solubilizing ability is able to induce stress related proteins and enzymes and protect the paddy plant under salinity. The results suggested that inoculation of salt-stressed plants with KMB strain could reduce effects of saline stress, improved tolerance and enhanced growth. The applicability of these beneficial bacteria in different agroecosystems have been presented comprehensively under both normal and stress conditions to highlight the recent trends with the aim to develop future insights.

\section{Conclusion}

Mineral fertilizers first became familiar in an earlier era in the agriculture field, to reduce the difficulties faced by farmers and for sustainable production of crops. To overcome the drawback of chemical fertilizers and to increase plant nutrient status and yield in a sustainable way, the biofertilizers then began to be used. Moreover, KMB species specifically are well known for their capability to solubilize rock to enhance potassium availability in agricultural soils, besides increasing mineral contents in plants. Plants inoculated with such KMB have enhanced plant growth and acquire a better capacity for salt tolerance, correlated with regulation of ion concentrations. The extensive use of chemical fertilizers in agriculture may reduce with the wide-scale use of KMB biofertilizers. Further investigation and understanding of mechanisms of KMBmediated phytostimulation would help us to find more capable rhizobacterial strains having the ability to function efficiently under different agro-ecological conditions for sustainable agriculture.

\section{Conflict of interest statement}

Authors declare that they have no conflict of interests. 


\section{References}

Bhattacharyya, P. N., Jha, D. Plant growthpromoting rhizobacteria (PGPR): emergence in agriculture. World Journal of Microbiology and Biotechnology, v. 28, no. 4, p. 1327-1350, 2012. https://doi.org/10.1007/s11274-011-0979-9

Chakraborty, U.; Roy, S.; Chakraborty, A.; Pratim, D. P.; Chakraborty, B. Plant growth promotion and amelioration of salinity stress in crop plants by a salt-tolerant bacterium. Recent Research in Science and Technology, v. 3, no. 11, p. 61-70, 2011. <https://scienceflora.org/ journals/index.php/rrst/article/view/824/808>.

Accessed on: Jun. 20, 2017.

Collavino, M. M.; Sansberro, P. A.; Mroginski, L. A.; Aguilar, O. M. Comparison of in vitro solubilization activity of diverse potassiumsolubilizing bacteria native to acid soil and their ability to promote Phaseolus vulgaris growth. Biology and Fertility of Soils, v. 46, p. 727738, 2010. https://doi.org/10.1007/s00374-0100480-X

Couée, I.; Sulmon, C.; Gwenola, G.; El Amrani, A. Involvement of soluble sugars in reactive oxygen species balance and responses to oxidative stress in plants. Journal of Experimental Bototany, v. 57, p. 449-459, 2006. https://doi.org/10.1093/jxb/erj027

Egilla, J. N.; Davies, F. T.; Boutton, T. W. Drought stress influences leaf water content, photosynthesis, and water-use efficiency of hibiscus Rosa sinensis at three potassium concentrations. Photosynthetica, v. 43, p. 135140, 2005. https://doi.org/10.1007/s11099-0055140-2

Jha, Y.; Subramanian, R. B.; Patel, S. Combination of endophytic and rhizospheric plant growth promoting rhizobacteria in Oryza sativa shows higher accumulation of osmoprotectant against saline stress. Acta Physiologiae Plantarum, v. 33, no. 3, p. 797802, 2011. https://doi.org/10.1007/s11738-0100604-9

Jha, Y.; Subramanian, R. B. Root associated bacteria from the rice antagonizes the growth of Magnaporthe grisea. Journal of Plant Pathology \& Microbiology, v. 4, no. 2, 2013a. https://doi.org/10.4172/2157-7471.1000164

Jha, Y.; Subramanian, R.B. Paddy physiology and enzymes level is regulated by Rhizobacteria under saline stress. Journal of Applied Botany and Food Quality, v. 85, p. 168-173, $2013 \mathrm{~b}$. Available from: <https://ojs.openagrar.de/ index.php/JABFQ/article/view/2317/2662>. Accessed on: May 22, 2017.
Jha, Y.; Subramanian, R.B. 2014a. Characterization of root-associated bacteria from paddy and its growth-promotion efficacy. 3 Biotech, v. 4, no. 3, p. 325-330. https://doi.org/10.1007/s13205-013-0158-9

Jha, Y.; Subramanian, R.B. Under saline stress plant growth promoting bacteria affect growth, photosynthesis and antioxidant activities in paddy. International Journal of Agriculture, Environment \& Biotechnology, v. 7, p. 489497, 2014b.

Kohler, J.; Hernandez, J. A.; Caravaca, F.; Roldan, A. Induction of antioxidant enzymes is involved in the greater effectiveness of a KMB versus AM fungi with respect to increasing the tolerance of lettuces to severe salt stress. Environmental and Experimental Botany, v. 64, no. 2/3, p. 207-216, 2008. https://doi.org/10.1016/j.envexpbot.2008.09.008 Liu, W.; Xu, X.; Wu, S.; Yang, Q.; Luo, Y.; Christie, P. Decomposition of silicate minerals by Bacillus mucilaginosus in liquid culture. Environmental Geochemistry and Health, v. 28, no. 1/2, p. 133-140, 2006. https://doi.org/10.1007/s10653-005-9022-0

Madhava Rao, K. V., Sresty, T. V. S. Antioxidative parameters in the seedlings of pigeon pea (Cajanus cajan (L.) Millspaugh) in response to $\mathrm{Zn}$ and Ni stresses. Plant Science, v. 157, no. 1, p. 113-128, 2000. https://doi.org/10.1016/S0168-9452(00)00273-9

Meena, V. S.; Maurya, B. R.; Verma, J. P. Does a rhizospheric microorganism enhance $\mathrm{K}+$ availability in agricultural soil? Microbiological Research, v. 169, no. 5/6, p. 337-347, 2014. https://doi.org/10.1016/ j.micres.2013.09.003

Meena, V. S.; Maurya, B. R.; Verma, J. P.; Arora, A.; Kumar, A.; Kim, K.; Bajpai, V. K. Potassium solubilizing rhizobactera (KSR): isolation, identification and K-release dynamics from waste mica. Ecological Engineering, v. 81, p. 340-347, 2015. https://doi.org/10.1016/ j.ecoleng.2015.04.065

Merlin, N. J.; Parthasarathy, V.; Manavalan, R.; Kumaravel, S. Chemical investigation of aerial parts of Gmelina asiatica Linn by GCMS. Pharmacognosy Research, v. 1, no. 3, p. 152156, 2009

Mia, M. A. B., Shamsuddin, Z. H., Mahmood, M. Use of plant growth promoting bacteria in banana: a new insight for sustainable banana production. International Journal of Agriculture \& Biology, v. 12, p. 459-467, 2010. Available from: <http://psasir.upm.edu. my/12408/1/Use_of_Plant.pdf $>$. Accessed on 
Jun. 23, 2017.

Rejšková, A.; Patková, L.; Stodůlková, E.; Lipavská, H. The effect of abiotic stresses on carbohydrate status of olive shoots (Olea europaea L.) under in vitro conditions. Journal of Plant Physiology, v. 164, p. 74-184, 2007. https://doi.org/10.1016/j.jplph.2005.09.011

Romheld, V.; Kirkby, E. A. Research on potassium in agriculture: needs and prospects. Plant and Soil, v. 335, p. 155-180, 2010. https://doi.org/10.1007/s11104-010-0520-1

Selvakumar, G.; Kundu, S.; Gupta, A. D.; Shouche, Y. S.; Gupta, H. S. Isolation and characterization of nonrhizobial plant growth promoting bacteria from nodules of Kudzu (Pueraria thunbergiana) and their effect on wheat seedling growth. Current Microbiology, v. 56, no. 2, $\quad$ p. 134-139, 2008. https://doi.org/10.1007/s00284-007-9062-z

Sivritepe, N.; Sivritepe, H.Ö.; Türkan, I.; Bor, M.; Özdemir, F. NaCl pretreatment mediate salt adaptation in melon plant through antioxidative system. Seed Science and Technology, v. 36, no. 2, p. 360-370, 2008. https://doi.org/ 10.15258/sst.2008.36.2.09

Whitelaw, M. A.; Harden, T. J.; Helyar, K. R. Potassium solubilization in solution culture by the soil fungus Penicillium radicum. Soil Biology and Biochemistry, v. 31, no. 5, p. 655665, 1999. https://doi.org/10.1016/S00380717(98)00130-8

Yu, X.; Liu, X.; Zhu, T. H.; Liu, G. H.; Mao, C. Isolation and characterization of potassium solubilizing bacteria from walnut and their effect on growth and phosphorus mobilization. Biology and Fertility of Soils, v. 47, p. 437446, 2011. https://doi.org/10.1007/s00374-0110548-2

Zaidi, A.; Khan, M. S.; Ahemad, M.; Oves, M. Plant growth promotion by potassium solubilizing bacteria. Acta Microbiologica et Immunologica Hungarica, v. 56, no. 3, p. 263284, 2009. https://doi.org/10.1556/ AMicr.56.2009.3.6

License information: This is an open-access article distributed under the terms of the Creative Commons Attribution License, which permits unrestricted use, distribution, and reproduction in any medium, provided the original work is properly cited. 